\title{
MODEL MENTAL SISWA TENTANG TERMOKIMIA
}

\author{
Komang Melina Dewi ${ }^{1}$, I Wayan Suja ${ }^{2}$, I Dewa Ketut Sastrawidana ${ }^{3}$ \\ Universitas Pendidikan Ganesha \\ Singaraja, Indonesia
}

e-mail: komang.melina.dewi.@undiksha.ac.id, wayan.suja.@undiksha.ac.id, ketut.sastrawidana.@undiksha.ac.id

\begin{abstract}
Abstrak
Penelitian ini bertujuan mendeskripsikan dan menjelaskan profil model mental dan faktor-faktor penyebab terbentuknya model mental alternatif siswa kelas XI tentang termokimia di SMA Negeri Bali Mandara. Penelitian ini menggunakan mixed methods jenis sekuensial. Pengumpulan data dilakukan dengan observasi, pemberian tes hasil belajar dua tingkat, dan wawancara. Analisis data dilakukan secara deskriptif berdasarkan hubungan antara jawaban siswa dan argumentasinya dengan melibatkan tiga level kimia. Teknik analisis data hasil wawancara meliputi tahap reduksi data, penyajian data, dan penarikan kesimpulan. Hasil penelitian ini menunjukkan bahwa profil model mental siswa kelas XI tentang termokimia, meliputi 1,94\% model mental ilmiah dan $98,05 \%$ model mental alternatif, yang terdiri atas 28,19\% miskonsepsi khusus dan 69,86\% benar sebagian. Faktor-faktor penyebab terbentuknya model mental alternatif pada pikiran siswa, meliputi rendahnya minat belajar siswa, kurangnya pemahaman siswa tentang termokimia, kurangnya perhatian siswa ketika pembelajaran, metode mengajar yang diterapkan guru tidak mencankup tiga level kimia dan padatnya kegiatan sekolah.
\end{abstract}

Kata kunci: termokimia, model mental, model mental alternatif.

\begin{abstract}
This research was aimed describe and explain the profile of the mental models and the factors that cause the formation of alternative mental models of class XI students about thermochemistry at Bali Mandara High School. This research uses a sequential type mixed methods. Data collection was carried out by observation, giving two-level learning outcomes tests, and interviews. Data analysis is carried out descriptively, based on the relationship between student answers and their arguments involving three chemical levels. The technique of analyzing data from interviews includes the stages of data reduction, data presentation, and conclusion drawing. The results of this research indicate that the profile of the mental model of class XI students about thermochemistry includes $1.94 \%$ of the scientific mental model and $98.05 \%$ of the alternative mental models, which consist of $28.19 \%$ special misconceptions and $69.86 \%$ are partly correct. Factors that cause the formation of alternative mental models on the minds of students, including the low interest in student
\end{abstract}


learning, lack of student understanding of thermochemistry, lack of attention of students when learning, teaching methods applied by teachers do not cover three chemical levels and the density of school activities.

Keywords: thermochemistry, mental models, alternative mental models.

\section{PENDAHULUAN}

Pembelajaran konsep-konsep kimia hendaknya melibatkan tiga level representasi, yaitu level makroskopis, level submikroskopis, dan level simbolik. Level makroskopis bersifat nyata, merupakan fenomena kimia yang dapat dijelaskan sesuai dengan fakta yang terlihat. Level submikroskopis juga bersifat nyata, namun menunjukkan eksistensi pada tingkat partikulat, berupa atom, ion, dan molekul. Sedangkan, level simbolik adalah level representasi berupa simbol, persamaan kimia dan perhitungan kimia (Johnstone, 1991). Pemahaman siswa terhadap tiga level kimia dan interkoneksinya diungkapkan sebagai model mental (Handayanti et al., 2015).

Model mental dapat direpresentasikan secara intrinsik berupa objek, ide, atau proses yang muncul selama berlangsungnya proses kognitif dalam memberikan alasan, menggambarkan, dan menjelaskan suatu fenomena. Siswa cenderung lebih banyak menggunakan transformasi level makroskopis ke simbolik dan sebaliknya (Wang, 2007; Devetak, 2009).

Penelitian model mental siswa dalam pembelajaran kimia penting dilakukan untuk mengevaluasi kemampuan siswa dalam menghubungkan fenomena makroskopis, submikroskopis dan representasi simbolik. Representasi submikroskopis adalah faktor kunci pada kemampuan tersebut. Ketidakmampuan mempresentasikan level submikroskopis dapat menghambat kemampuan memecahkan permasalahan berkaitan dengan fenomena makroskopis dan representasi simbolik (Chandrasegara, et al., 2007).

Salah satu bahan kajian kimia yang diajarkan di kelas XI SMA adalah termokimia. Termokimia merupakan cabang ilmu kimia yang mempelajari energi yang menyertai perubahan fisika atau reaksi kimia (Whitten et al., 2004). Termokimia merupakan konsep penting untuk dipahami siswa. Pada kenyataannya, pemahaman siswa pada materi termokimia apalagi dengan melibatkan tiga level kimia masih. rendah. Sutisna (2013) mengungkapkan bahwa nilai rata-rata ulangan siswa paling rendah pada materi kimia SMA yang diajarkan di kelas XI adalah termokimia. Selain itu, menurut Ayyildiz dan Tahran (2012), salah satu materi kimia yang dianggap sulit adalah reaksi kimia dan energinya.

Salah satu cara untuk mengetahui model mental siswa adalah dengan memberikan tes pilihan ganda dua tingkat (two-tier). Mengingat tes model mental mengukur kemampuan siswa untuk menjelaskan data, memprediksi kejadian, dan menjelaskan fenomena makroskopis kimia dengan melibatkan penalaran pada level submikroskopis menggunakan bahasa simbolik kimia, maka pemberian tes diagnostik model mental diharapkan dapat mengukur pemahaman siswa tentang konsep-konsep kimia (Coll \& Taylor, 2002).

Hasil penelitian yang dilakukan oleh Liliawati \& Ramalis (2008) menunjukkan, faktor penyebab terjadinya model mental disebabkan oleh adanya miskonsepsi yang dialami siswa serta ketidakpahaman tiga level kimia secara utuh. Faktor penyebab terjadinya miskonsepsi digolongkan menjadi lima yaitu kondisi siswa, guru, metode mengajar, buku kimia, dan konteks.

Hasil studi pendahuluan yang telah dilakukan dengan wawancara pada guru kimia kelas $\mathrm{XI}$ di SMA Negeri Bali Mandara menunjukkan bahwa bahan kajian termokimia merupakan salah satu topik yang susah dipahami oleh siswa. Kesulitan siswa tidak hanya terjadi pada perhitungannya, tetapi membedakan $\Delta \mathrm{H}$ reaksi pembentukan, penguraian, dan pembakaran yang mengakibatkan sebagian besar siswa memperoleh nilai dibawah 75 sedangkan KKM nya yaitu 75 sehingga siswa belum mencapai KKM untuk mata pelajaran kimia.

Berdasarkan hasil temuan tersebut perlu dilakukan penelitian berkaitan dengan pemahaman siswa tentang interkoneksi ketiga level kimia pada bahan kajian termokimia di SMA Negeri Bali Mandara. Penelitian ini bermaksud untuk mengkaji lebih lanjut mengenai profil model mental siswa dan mengidentifikasi faktor-faktor yang mempengaruhi pembentukan model mental alternatif siswa kelas XI pada materi termokimia di SMA Negerii Bali Mandara. 


\section{METODE}

Penelitian ini adalah penelitian mixed methods dan jenis sekuential. Penelitian dilaksanakan di SMA Negeri Bali Mandara pada bulan desember 2018 - januari 2019. Populasi dalam penelitian ini adalah seluruh siswa dijadikan subjek penelitian. Kelas XI MIPA di sekolah ini terdiri dari 3 kelas. Jumlah siswa setiap kelas 27 orang dengan jumlah total siswa kelas XI adalah 81 orang pada tahun ajaran 2018/2019. Data yang diperoleh dikumpulkan melaui metode observasi, pemberian tes hasil belajar dua tingkat dan wawancara. Instrumen yang digunakan adalah pedoman observasi, pedoman wawancara, dan soal model mental. Teknik analisis dilakukan secara deskriptif, berdasarkan hubungan antara jawaban siswa dan argumentasinya dengan melibatkan tiga level kimia. Teknik analisis data hasil wawancara meliputi tahap reduksi data, penyajian data, dan penarikan kesimpulan. Data pada penelitian ini berupa hasil belajar tes model mental dan faktor- faktor penyebab terbentuknya model mental alternatif

\section{HASIL DAN PEMBAHASAN}

Hasil tes dalam bentuk skor jawaban siswa terhadap tes model mental siswa dua tingkat disajikan dalam bentuk tabel yang berisi no urut, kode siswa, dan skor siswa. Jawaban siswa terhadap tes model mental tersebut menggambarkan kemampuan siswa dalam merepresentasikan tiga level kimia, yaitu makroskopis, submikroskopis dan simbolik serta interkoneksinya. Adapun faktor-faktor yang mempengaruhi terbentuknya model mental alternatif antara lain kurangnya perhatian siswa saat mengikuti pembelajaran di kelas, kurangnya minat belajar siswa, pemahaman konsep yang masih rendah, strategi yang digunakan guru saat mengajar dengan menerapkan konsep dan lebih menekankan pada level makroskopik dan simbolik saja serta padatnya kegiatan yang ada di sekolah. Profil model mental siswa tentang kajian termokimia ditampilkan pada Tabel 1.

Tabel 1. Profil model mental siswa

\begin{tabular}{|c|c|c|c|c|c|c|c|c|c|c|}
\hline \multirow{3}{*}{ No } & \multirow{3}{*}{ Indikator } & \multirow{3}{*}{$\begin{array}{l}\text { No } \\
\text { Soal }\end{array}$} & \multicolumn{8}{|c|}{ Model Mental } \\
\hline & & & \multicolumn{2}{|c|}{ SC } & \multicolumn{2}{|c|}{ PC } & \multicolumn{2}{|c|}{ SM } & \multicolumn{2}{|c|}{ NR } \\
\hline & & & $\Sigma$ & $\%$ & $\Sigma$ & $\%$ & $\Sigma$ & $\%$ & $\Sigma$ & $\%$ \\
\hline 1 & $\begin{array}{l}\text { Menentukan } \\
\text { sistem/lingkung } \\
\text { an berdasarkan } \\
\text { hasil percobaan }\end{array}$ & $\begin{array}{l}1 \\
2\end{array}$ & 0 & 0 & 56 & $\begin{array}{l}77,78 \\
83,33\end{array}$ & 16 & $\begin{array}{l}22,22 \\
16,67\end{array}$ & 0 & 0 \\
\hline 2 & $\begin{array}{l}\text { Menganalisis } \\
\text { reaksi } \\
\text { eksoterm } \\
\text { /endoterm } \\
\text { berdasarkan } \\
\text { hasil } \\
\text { percobaan }\end{array}$ & 3 & 0 & 0 & 36 & 69,44 & 22 & 30,56 & 0 & 0 \\
\hline 3 & $\begin{array}{l}\text { Menentukan } \\
\text { reaksi } \\
\text { eksoterm/endet } \\
\text { erm berdasarkan } \\
\text { diagram tingkat } \\
\text { energi. }\end{array}$ & 5 & 1 & 4,17 & 55 & 76,39 & 14 & 19,44 & 0 & 0 \\
\hline 4 & $\begin{array}{l}\text { Menghitung } \Delta \mathrm{H} \\
\text { reaksi } \\
\text { berdasarkan data } \\
\text { percobaan } \\
\text { calorimeter }\end{array}$ & 7 & 4 & 5,56 & 40 & 55,56 & 28 & 38,89 & 0 & 0 \\
\hline 5 & $\begin{array}{l}\text { Menghitung } \Delta \mathrm{H} \\
\text { reaksi } \\
\text { berdasarkan } \\
\text { hukum Hess }\end{array}$ & 8 & 0 & 0 & 58 & 80,56 & 14 & 19,44 & 0 & 0 \\
\hline
\end{tabular}




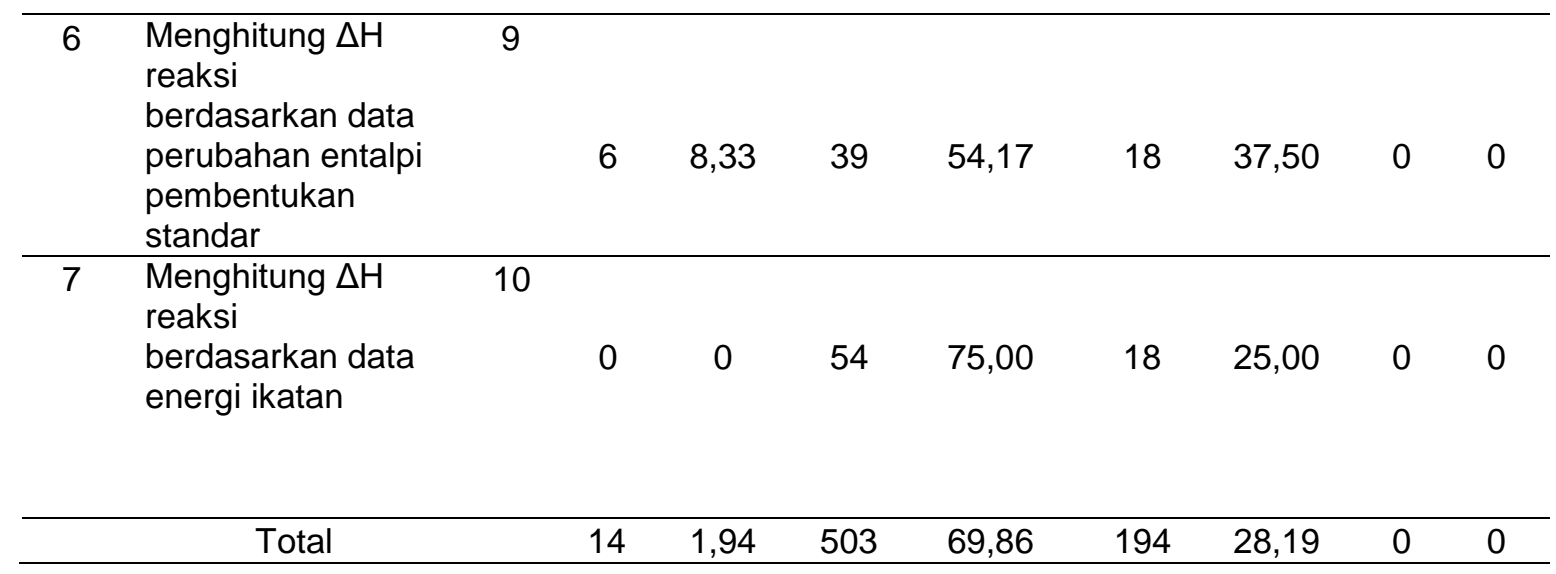

\section{Keterangan:}

SC = model mental ilmiah (Scientifically Correct) $\mathrm{PC}=$ benar sebagian (Partially correct)

$$
\begin{aligned}
& \mathrm{SM}=\text { miskonsepsi khusus (Specific Misconceptions) } \\
& \mathrm{NR}=\text { tidak ada tanggapan atau tidak memiliki konsep (No Response) }
\end{aligned}
$$

Data profil model mental berdasarkan persentase masing-masing kategori disajikan dalam bentuk diagram pie pada gambar 1 .

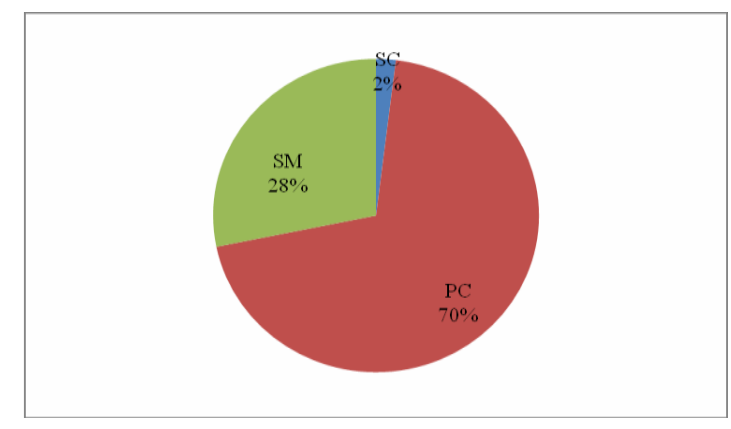

Gambar 1. Diagram pie profil model mental siswa berdasarkan presentase masing-masing model mentalnya.

Hanya 1,94\% konsep-konsep Termokimia dipahami oleh siswa kelas XI SMA Negeri Bali Mandara dalam bentuk model mental ilmiah, sedangkan sisanya sebanyak $98,05 \%$ dalam bentuk model mental alternatif. Model mental alternatif tersebut terdiri atas model mental benar sebagian sebanyak $69,86 \%$, dan model mental miskonsepsi khusus sebanyak $28,19 \%$. Model mental ilmiah hanya dimiliki oleh siswa berkaitan dengan menghitung $\Delta \mathrm{H}$ reaksi berdasarkan data percobaan kalorimeter. Persentase tertinggi untuk model mental benar sebagian sebesar $8,33 \%$ berkaitan dengan menentukan sistem/lingkungan berdasarkan hasil percobaan. Siswa Model mental miskonsepsi khusus memiliki persentase tertingi 5,00\% tentang menganalisis reaksi eksoterm lendoterm berdasarkan hasil percobaan.

Temuan penelitian ini menunjukkan bahwa siswa memiliki pemahaman yang rendah terkait interkoneksi tiga level kimia tentang bahan kajian termokimia, yang terutama disebabka oleh ketidakmampuannya untuk memeberikan argumentasi pada level submikroskopis. Ketidakpahaman siswa dalam mengaitkan ketiga level kimia menyebabkan tidak utuhnya pemahaman siswa tentang termokimia.

Pada indikator pertama, sebagian besar model mental siswa dalam bentuk benar sebagian (PC). Siswa mampu menentukan sistem dan lingkungan dalam suatu reaksi kimia, tetapi tidak mampu menjelaskannya pada level partikel materi. Secara keilmuan, yang termasuk sistem dalam suatu reaksi kimia adalah reaktan dan produk. Perubahan reaktan menjadi produk disertai dengan terjadinya pelepasan / penyerapan energy (kalor). Secara submikroskopis, proses tersebut melibatkan transformasi atom, ion, dan molekul dari reaktan menjadi produk. Temuan ini di sejalan dengan hasil penelitian Murniarti et al (2015) yang menyatakan bahwa miskonsepsi siswa pada 
sub bab sistem dan lingkungan terjadi pada level submikroskopis. Pada indikator kedua dan ketiga mengenai kompetensi siswa untuk menganalisis reaksi eksoterm/endoterm berdasarkan hasil percobaan, sebagian besar dipahami dalam bentuk model mental benar sebagian. Kondisi itu disebabkan oleh ketidakpahaman siswa dalam menjawab soal pada level submikroskipis. Secara keilmuan, reaksi eksoterm/ endotrm terjadi ketika suatu reaksi melibatkan transformasi atom, ioion dan molekul dari pereaksi menjadi hasil reaksi sehingga menyebabkan entalpi sistem berkurang ataupun bertambah. Temuan ini sejalan dengan hasil penelitian Susanty (2010) yang menyatakan bahwa hampir seluruh siswa memiliki model mental sederhana pada level submikroskopis dan kesulitan dalam menghubungkan ketiga level kimia sehingga siwa memiliki model mental alternatif.

Pada indikator keempat, tentang kompetensi siswa untuk menghitung $\Delta \mathrm{H}$ reaksi berdasarkan kalorimeter distribusi model mental benar sebagian (PC) menyumbangkan persentase tertinggi. Kondisi ini disebabkan oleh kelemahan siswa dalam menjelaskan level submikroskopis dan level simbolik. Pada level molekuler dan pada level simbolik hanya beberpa siswa yang dapat menuliskan persamaan reaksi dan perhitungan kimia dalam mencari $\Delta \mathrm{H}$ reaksi netralisasinya. Secara keilmuan pada level submikroskopis kation hidrogenium dari asam klrida bereaksi dengan anion hidroksida dari natrium hidroksida menghasilkan molekul-molekul air disertai dengan terjadinya pelepasan kalor. Pada level simbolik, persamaan reaksinya sebagai berikut.

$$
\begin{aligned}
& \mathrm{HCl}_{(\mathrm{aq})}+\mathrm{NaOH}(\mathrm{aq}) \quad \mathrm{NaCl}(\mathrm{aq})+\mathrm{H}_{2} \mathrm{O}(\mathrm{l}) ; \Delta \mathrm{Hn} \\
& =-57,71 \mathrm{~kJ} / \mathrm{mol} .
\end{aligned}
$$

Data tersebut sejalan dengan hasil penelitian Handayani (2015) yang menyatakan siswa cenderung tidak mengerti representasi fenomena submikroskopis dari suatu reaksi kimia.Pada indikator kelima, tentang kompetensi siswa untuk menghitung $\Delta \mathrm{H}$ reaksi berdasarkan hukum Hess, distribusi model mental benar sebagian juga tergolong paling tinggi. Siswa tidak dapat menjelaskan pada tingkat molekuler dan pada level simbolik, hanya beberapa siswa dapat membuat diagram tingkat energinya. Secara keilmuan, atom-atom karbon bereaksi dengan molekul-molekul oksigen membentuk molekul-molekul karbonmonoksida. Selanjutnya, molekul karbonmonoksida bereaksi dengan molekul- molekul oksigen menghasilkan molekul- molekul karbondioksida. Temuan ini sejalan dengan penelitian Susanty (2010) yang menyatakan siswa sebagian besar memiliki model mental yang rendah dalam menjelaskan level simbolik kedalam bentuk diagram pada level submikroskopis. Kompetensi siswa untuk menghitung $\Delta \mathrm{H}$ reaksi berdasakan data perubahan entalpi pembentukan standar pada indikator enam, distribusi model mental benar sebagian dan model mental miskonsepsi khusus berbanding tipis. Kondisi ini terbentuk karena sebagian siswa tidak mampu.memberikan penjelasan pada level submikroskopis dan level simbolik. Secara keilmuan molekul gas metana bereaksi dengan molekul oksigen membentuk molekul karbondioksida dan molekul air. Perhitungan kimianya yaitu menghitung selisih antara produk dan reaktan. Temuan ini sejalan dengan penelitian Handayani (2015) yang menyatakan siswa memiliki memiliki model mental sederhana dalam menjelaskan level simbolik dan level submikroskopis.

Indikator ketujuh, tentang kompetensi siswa untuk menghitung $\Delta \mathrm{H}$ reaksi berdasarkan data energi ikatan, sebagian besar dipahami dalam bentuk model mental benar sebagian, hal tersebut disebabkan lemahnya pengetahuan siswa pada level submikroskopis dan simbolik. Secara keilmuan, reaksi oksidasi molekul metanol menjadi molekul formaldehid dan molekul air. Perhitungan kimia menghitung selisih antara pemutusan ikatan dan pembentukan ikatan. Temuan ini sejalan dengan hasil penelitian Susanty (2010) yang menyatakan siswa memiliki model mental yang rendah pada level submikroskopis sehingga, siswa memiliki kesulitan dalam menghubungkan ketiga level kimia.

Berdasarkan hasil observasi dan wawancara beberapa orang siswa, ditemukan beberapa faktor yang mempengaruhi model mental alternatif, yaitu faktor internal dan faktor eksternal. Faktor internal adalah faktor yang berasal dari dalam diri siswa. Beberapa faktor internal penyebab model mental alternatif adalah sebagai berikut.

Pertama, kurangnya perhatian siswa saat mengikuti pelajran di kelas. Berdasrkan observasi di kelas masih banyak siswa yang kurang fokus dalam menerima pelajaran. Selain itu dari hasil wawancara, siswa menyatakan kurang memperhatikan penjelasan guru di kelas karena tidak memahami materi yang diajarkan. Hal ini sependapat dengan sucitra (2016) yang menyatakan siswa kurang perhatian terhadap proses pembelajaran. 
Kedua, minat belajar siswa yang masih rendah. Berdasarkan hasil wawancara, rendahnya minat belajar karena siswa menggangap pelajaran kimia khususnya termokimia itu sulit. Minat dapat mempengaruhi proses pembejalaran di kelas, apabila tidak sesuai dengan minat siswa maka sisw tidak akan benar-benar mempelajari materi tersebut dengan baik.

Ketiga, pemahaman konsep siswa masih rendah. Kebanyakan siswa tidak memiliki pemahaman konsep karena siswa hanya sekedar menghafal. Hal ini diperkuat dari pernyataan guru kimia kelas $\mathrm{XI}$ menyatakan siswa masih mengalami kesulitan dalam menetukan reaksi pembentukan, pembakarran dan penguraian selain itu juga masih bingung dalam menetukan reaksi endoterm dan eksoterm.Selain faktor internal adapula faktor eksternal. Faktor eksternal adalah faktor yang berasal dari luar diri siswa. Faktor- faktor penyebab terbentuknya model mental alternatif yang berasal dari luar diri siswa adalah sebagai berikut. Pertama, padatnya kegiatan siswa yang membuat menurunnya minat dan kosentrasi siswa dalam mengikuti pembelajaran dikelas serta dalam pengumpulan tugas yang tidak sesuai dengan batas waktu yang telah ditentukan ini dibuktikan dari hasil wawnacara dan didukung oleh hasil observasi.Kedua, strategi yang digunakan guru saat mengajar dengan menerapkan konsep dan lebih menekankan pada level makroskopik dan simbolik saja.

Rendahnya pemahaman siswa dalam mempresentasikan ketiga level kimia juga ditemukan pada penelitian Handayani (2015). Temuan ini sejalan dengan penelitian Susanty (2010) yang menyatakan hampir seluruh siswa memiliki model mental yang sederhana pada level submikroskopis dan siswa kesulitan dalam menghubungkan ketiga level kimia. Hasil penelitian Suja (2015) juga mendapatkan, ketidakutuhan pemahaman mahasiswa tentang ketiga level representative dan interkoneksinya

pada bahan kajian stereokimia. Selain itu, penelitian sucitra (2016) menyatakan siswa belum dapat memahami hubungan struktur molekul terhadap sifat senyawa organik yang mencangkup ketiga level kimia dan interkoneksinya. Hal yang sama juga ditemukan pada penelitian Retno Puji astuti (2017), menyatakan siswa belum mampu mengkaitkan ketiga level kimia dengan interkoneksinya. Seluruh hasil penelitian tersebut memberikan hasil yang sama, yaitu rendahnya pemahaman siswa terkait representasi ketiga level kimia beserta interkoneksinya yang menyebabkan ketidakutuhan pemahaman siswa

\section{SIMPULAN DAN SARAN}

Berdasarkan hasil penelitian diatas, simpulan dalam penelitian ini adalah sebagai berikut.

1. Profil model mental siswa kelas xi sma negeri bali mandara tentang termokimia sebanyak $1,94 \%$ siswa mengalami model mental ilmiah dan sebanyak $98,05 \%$ siswa memiliki model mental alternatif, yang meliputi $69,86 \%$ model mental benar sebagian, $28,19 \%$ memiliki model mental miskonsepsi khusus.

2. Faktor-faktor penyebab terbentuknya model mental alternatif pada siswa yaitu faktor internal diantaranya kurangnya perhatian siswa saat mengikuti pembelajaran, minat belajar siswa masih rendah, dan pemahaman konsep siswa masih rendah sedangkan faktor eksternal adalah guru dan banyaknya kegiatan yang ada disekolah.

Sejalan dengan hasil penelitian dapat disampaikan saran sebagai berikut, yaitu guru kimia di SMA perlu menerapkan metode dan strategi pembelajaran yang tepat tentang bahan kajian termokimia khususnya pada level submikroskopis agar pembelajaran berlangsung lebih efektif dan efisien serta siswa memiliki model mental ilmiah.

\section{DAFTAR RUJUKAN}

Ayyildiz, Y. \& Tarhan, L. 2012. The Effective Concepts on Student's Understanding Of Chemical Reactions And Energy. Hacettepe Universitesi Journal Of Education, 1 (42: 72-83

Chandrasegaran, A. L,. F Treagust. David,. \& M. Mauro. 2007. The Development of a Two-Tier Multiple-Choice Diagnostic Instumen for Evawating Secondary School Students' Ability to Describe and Explain Chemical Reactions Using Multiple-Choice. Chemistry Education Research and Prantice. 8 (3): 293-307.

Chang, R. 2005. Kimia Dasar Konsep- Konsep Inti, Edisi Ketiga Jilid I. Jakarta: Erlangga. 
Chittleborough, G. 2004. The Role of Teaching Models and Chemical Representions of the Role of Models in The Process of Sicience and The Process of Leaning. Research in Science and Technological Education. 23(2): 195-212.

Coll, R. K., \& Taylor, N. (2002). Mental Models in Chemistry: Senior Chemistry Students. Mental Models of Chemical Boding. Chemistry Education: Research and Practice in Europe, 3(2):175-184.

Creswell, John, W. 2010. Reseach Desain Qualitative Quantitative, and Mixed Methods Approaches. Lincoln: Unversity of PNerbraska.

Devetak, I., Lober, E. D., Juriservic, M., \& Glzar, S. A. 2009. Comparing Slovenian Year 8 and Year 9 Elementary School Pupils Knowlodge of Electrolyte Chemistry and Their Intrinstic Motivation. Chemistry Education Research And Practice, 10(4):281-290

Furio, C. \& Calatayud, M. L. 1996. Difficulties with The Geometry and Polarity of Molecules. Journal of Chemical Education, 73(1):36-41

Handayanti, Y. Setiabudi, A., \& Nahadi. 2015. Analisis Profil Model Mental Siswa SMA pada Materi Laju Reaksi. Jurnal Penelitian dan Pembelajran IPA, 1(1):107- 122.

Ibrahim, M. 2010. Seri Pembelajaran Inovatif: Konsep Miskonsepsi, dan Cara Pembelajaran. Surabaya: Usesa University Press

Jansoon, N,. Coll, R.K.,\& Somsook,E. 2009. Undestending Mental Models of Dilution in Thai Students. Inernational Journal of Environmental \& Science Education , 4(2):147-168.

Johnstone, A. H. 1991. Why is Science Difficult to learn? Thing are Seldom What They seem. Journal of Computer Assisted Learning. 7(2):75-83.

Liliawati, W. \& Ramalis, T. R. 2008. Identifikasi Miskonsepsi Materi IPBA di SMA dengan menggunakan CRI ( Certaintly of Response Index) dalam Upaya Perbaikan Urutan Pemberian Materi IPBA pada KTSP. Jurnal Pendidikan Teknologi dan Kejuruan, 6(4):156168.

Nafiun. 2013. Bunyi Hukum Hess Termokimia, Contoh Soal, Rumus, Pratikum, Entalpi, Kimia. Tersedia pada www.nafiun.com/2013/06/bunyi- hukum-hess-termokimia-contohsoal.html?m=1

Park, E. J. 2006. Student Perception and Conceptual Development as Represented by Student Mental Models of Atomic Structure. Colombus: The Ohio State University.

Sendur, G., Toprak, M., \& Pekmez, E. 2010. Analyzing of Students misconception about Chemical Equilibrium. Makalah disajikan pada International Conference on New Trends in Education and Their Implication, Antalya (Turkey).

Suardana, I. Nyoman., Kirna, I. Made.,\& Retug, I. Nyoman. 2001. Kimia Fisika 1. Singaraja: IKIP Negeri Singaraja

Sucitra, I. G. B., Suja, I. W., Muderawan, I. W., \& Nurlita, F. 2016. Propil Model

$\begin{array}{ccccc}\text { Metal } & \text { Siswa } & \text { tenang Kolerasi } & \text { Strukt } & \text { Model } \\ \text { terhadap } & \text { Sifat } & \text { Senyawa Organik. } & \text { Proseding } & \\ \text { Seminar Nasional } & \text { FMIPA } & \text { UNDIKSHA 2016. } & \text { Singaraja. }\end{array}$

Universitas Pendidikan Ganesha. Tersedia pada http://ejournal.undiksha.ac.id

Sudarmo, Unggul. 2014. Kimia SMA Kelas XI K.2013. Jakarta: Erlangga

Sustina, Agustina. 2013. Pengembangan Model Pembelajaran Kognitif untuk MemfalisitasiPerubahan Konseptual dan Peningkatan Keterangan Berfikir Kritis Siswa pada Materi Termokimia. Skripsi Universitas Pendidikan Indonesia 
Sugiyono. 2012. Metode Penelitian Kuntitatif, Kualitatif dan R\&D. Bandung: Alfabeta.

Sugiyono. 2014. Metode Penelitian Pendidikan. Bandung: Alfabeta.

Suja, I. W., \& Retug, N. 2013a. Profil Konsepsi Kimia Siswa Kelas Xi di Kota Singaraja. Proseding Seminar Nasional Riset Inovatif 1. Singaraja: Undiksha

Suja, I., \& Retug, N. 2013b. Konsepsi Kimia Siswa Kelas XII di Kota Singaraja. Prosiding Seminar Nasional FMIPA UNDIKSHA III Tahun 2013 (hlm.125-133). Tersedia pada http:// ejournal.undiksha.ac.id.

Suja, I. W. 2015. Model Mental Mahasiswa Calon Guru Kimia dalam Memahami Bahan Ajar Stereokimia. Jurnal Pendidikan Indonesia, 4(2):625-638.

Suja, I. W. 2016. "Profil Model Mental Siswa Tentang Korelasi Struktur Molekul Terhadap Sifat Senyawa Organiki". ISBN 978-602-6428- 00-4. Tersedia pada http://ejournal.undiksha.ac.id (diakses tanggal 18 Juli 2018).

Sunyono, Yuanita, L., \& Ibrahim, M. 2015. Supporting Students in Learning With Multiple Representation to Improve Student mental Models on Atomic Structure Concepts. Science Education International, 26(2):104-125.

Susanty, P. 2010. Profil Model Mental Siswa pada Pokok Bahasan Larutan Elektrolit dan Non Elektrolit. Bandung.

Treagut, D.F, \& Coll, R. K. 2003. Investigetion of Secondary School, Undergraduate, and Graduate Leaners'Mental Models of Ionic Bonding. Journal of Reseach in Science Teaching. 40(5):464-486.

Wang, C. Y. 2007. The Rol of Mental- modelling Ability, Conten Knowledge and Mental Model in General Chemistry Student's Undestanding about Moleculer Polarity. A DisstertationPresented to the Graduate School University of Missouri- Colombia. Tersedia pada http://mospace.umsytem.edu.

Yuantonius. 2012. Kenali Perbedaan Reaksi Eksoterm dan Endoterm dengan mudah. Tersedia pada https://bisakimia.com/2012/ken ali-perbedaan-reaksi- eksoterm-dan-reaksi- endotermdengan-mudah/. 